\title{
SOIL QUALITY CHANGES FOLLOWING FOREST CLEARANCE IN BENGKULU, SUMATRA
}

\author{
I.P. HANDAYANI \\ Department of Soil Science, Agriculture College, University of Bengkulu \\ Bengkulu, Sumatra 38371 A, Indonesia
}

\begin{abstract}
Intense destruction and degradation of tropical forests is recognized as one of the environmental threats and tragedies. These have increased the need to assess the effects of subsequent land-use following forest extraction on soil quality. Therefore, the objective of this study is to evaluate the impacts of land-use type on soil quality properties in Bengkulu Province, Sumatra. Soil samples were collected from adjacent sites including natural secondary forest, bare land, cultivated land and grassland. The results show that land-use following forest clearance lowered saturated hydraulic conductivity (85\%), porosity (10.50\%), soil water content at field capacity (34\%),C organic (27\%), N total (26\%), inorganic N (37\%), soil microbial biomass C (32\%), mineralizable C (22\%), and particulate organic matter (50\%), but slightly increased water soluble organic C. Specific respiration activity rates increased about $14 \%$ in cultivated soils compared to natural forest soils, indicating greater $\mathrm{C}$ turnover per labile $\mathrm{C}$ pool in the form of soil microbial biomass, thus decreased biologically active soil organic matter. Forest conversion tends to reduce the $\mathrm{C}_{\text {,ffg }} / \mathrm{C}_{\mathrm{rer}}$ for all deforested sites. All of deforested areas relatively have infertile soil, with the worst case found in cultivated field. The $\mathrm{C} \wedge \mathrm{g} / \mathrm{Crd}$ of cultivated fields was about $24 \%$ less than that of remnant forest (1.07). Grassland apparently maintains only slightly higher soil C levels than the bare land. On average, degradation index of soil following forest clearance was 35\% with the highest deterioration occurred in the bare land (38\%). Fallowing the fields by naturally growth of Imperata cylindrica for about $15 \mathrm{yr}$ in abandoned land after 3-5 years of cultivation did not improve the soil quality. Moreover, forest clearance has an impact on soil quality as resulted in the loss of a physically protected organic matter and reduction in some labile $\mathrm{C}$ pools, thus declined biological activity at disturbed ecosystems.
\end{abstract}

Keywords: Degradation index / forest / Imperata cylindrica grassland / soil quality/ soil organic matter

\section{INTRODUCTION}

The integration among the primary natural resources - vegetation, soil and water, are important factors for maintaining terrestrial ecosystem functions and productivity. Human poverty and a continuous decline in the amount of agricultural area per family have led to exploitation of natural resources and deforestation on secondary forest in developing countries, such as Indonesia. Consequently, more forest land are converted to cropland at an alarming rate (Riswan and Hartanti 1995). These trends have caused a need to determine the effects of forest conversion and deforestation on soil quality.

Subsequent land-use change following deforestation or cultivation of deforested land may rapidly decline soil quality, as ecologically sensitive indicators of the tropical ecosystem are not able to buffer the impacts of land management practices. As a result, severe degradation in soil quality may lead to a permanent loss of land productivity (Handayani 2001;McDonald et al. 2002). Evaluation of soil 
properties upon land conversion tor varying agricultural purposes is most crucial to assess early changes in soil quality. Therefore, the specific objectives of this research were:(i) to determine and compare the changes in the physical, chemical and biological soil properties of soils in response to different land-use; and (ii) to calculate the degradation index of each tropical disturbed ecosystem.

\section{MATERIALS AND METHODS}

\section{Study Site}

The study site is located around The Rajo Lelo Forest Garden (KAWASAN TAMAN HUTAN RAYA RAJO LELO), $15 \mathrm{~km}$ north of Bengkulu City, Sumatra. The area was originally covered with typical tropical forest speces, such as Arthocarpus champede, Parkia spesiosa, Durio zibethinus, Pithecellobium latum, Cinnamomum porectum, Spondias pinnata Kurt, Rhodomnia cinerea, Areca sp. and Aporosa aurita. The forest have been cleared through cutting the wood to meet the increasing demands for timber and agricultural land. For more than 25 years, people living in the surrounding Forest Garden have often encroached upon and cultivated agricultural crops in the deforested land without using any fertilizer and soil conservation practices. These agricultural activities have caused regeneration of existing residual vegetation on clear-land and degraded deforested areas.

The climate of the area is tropical monsoon with rainy season occuring from September to March and dry season from April to August. The mean annual temperature is $26^{\mathrm{U}} \mathrm{C}$, while the mean rainfall is $200 \mathrm{~mm} / \mathrm{month}$. The soils are classified as very fine, mixed, isohyperthermic, Typic Palehumult, according to US Soil Taxonomy. These soils are poorly to moderately drained and occur on undulating to flat uplands. The elevation is below $50 \mathrm{~m}$ above sea level.

\section{Soil Sampling}

Surface soil samples at the depth interval of 0 to $15 \mathrm{~cm}$ were collected from three sites under each of four adjacent land-use/land cover types: (1) Secondary forest ('natural forest'), (2) Secondary forest cleared, and soil subsequently maintained weed-free ('bare land '), (3) Secondary forest cleared, burned and soil planted with annual vegetable crops for about 6 years ('cultivated land') and (4) Secondary forest cleared, burned and soil cultivated for about 5 years then abandoned, thus naturally grown by Imperata cylindrica for about 15 years ('grassland') (Figure 1.). For each site, 16 soil cores (1.9 cm diameter each) were randomly sampled and mixed to obtain a composite sample that was sealed in a plastic bag. Field-moist soil samples were gently sieved through a $2 \mathrm{~mm}$ mesh to remove stones, roots, and large organic residues and sealed in plastic bags to store at $4^{\circ} \mathrm{C}$. Soil biological analyses were carried out within 10 days of sampling after an overnight acclimatization period at room temperature. 


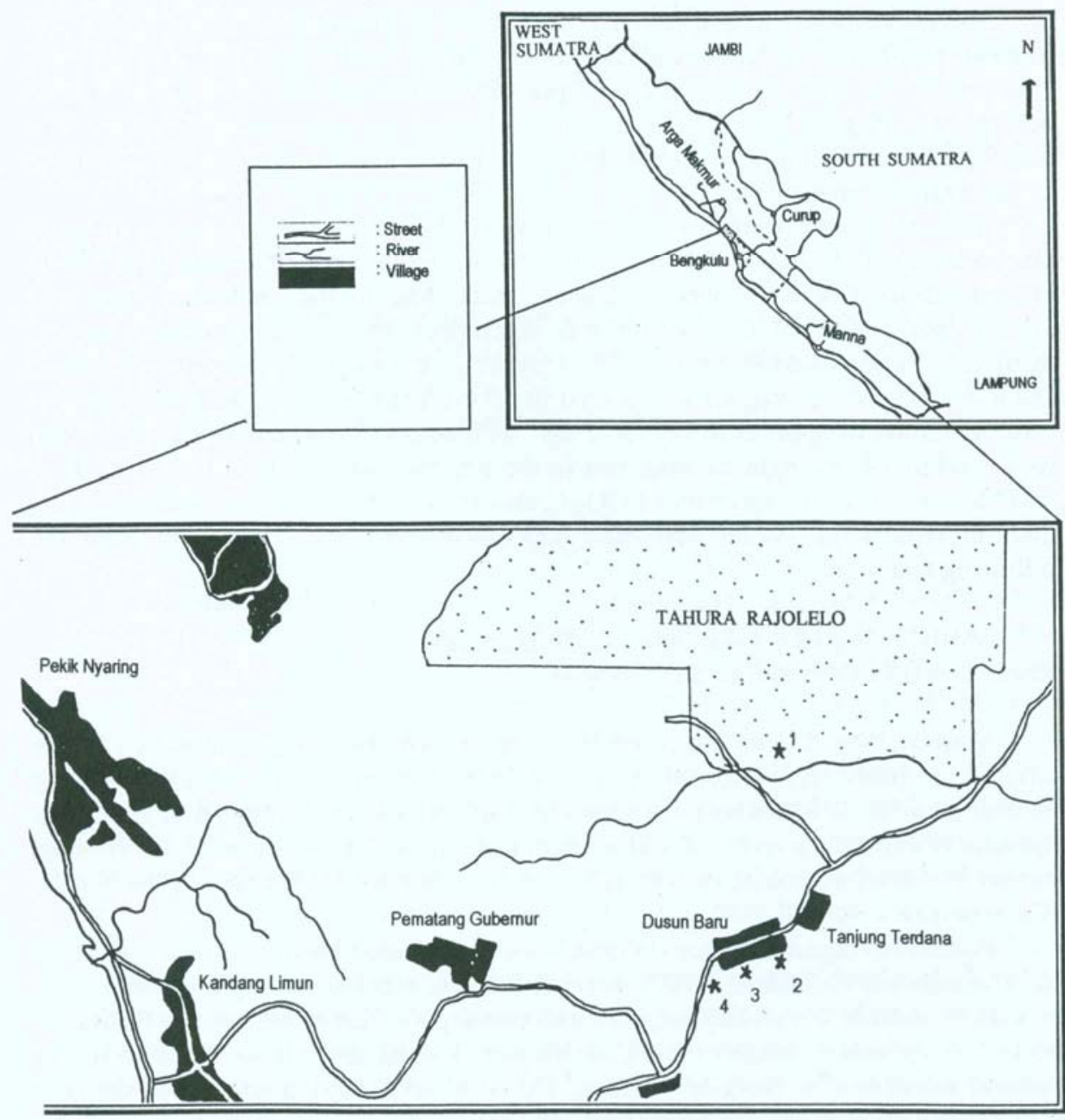

$1=$ Secondary forest ('natural forest')

2 = Bare land

3 = Cultivated land

$4=$ Grassland

Figure 1. Location of the study sites around TAHURA RAJOLELO in Bengkulu Province, Southern part of Sumatra. 


\section{Soil Physical, Chemical and Biological Analyses}

Saturated hydraulic conductivity (Ksat) was determined by the constant-head method according to Klute and Dierksen (1986). Soil bulk density (BD) was assessed by the core method and total porosity was calculated assuming a particle density of $2.65 \mathrm{~g} \mathrm{~cm}^{\prime 3}$. Gravimetric water field capacity was measured by pressure plate apparatus method (Scott et al. 1994). Soil particle size analysis was conducted by the hydrometer method.

Soil $\mathrm{pH}$ was determined in 1:2.5 soil-water slurry, using a combination of glass electrode. Total C (TC) and nitrogen (TN) contents were determined on finely ground air-dried soils by wet combustion according to the method of Kandeler (1995). Soil microbial C (SMBC) was determined by the fumigation-incubation method (Jenkinson and Powlson 1976) with the following modifications. Moist soil (30 g dry-weight equivalent) was placed in 50 -mL beakers, fumigated, brought to a water potential of approximately $-30 \mathrm{~J} \mathrm{~kg}^{11}$ with de-ionized water $(0.3 \mathrm{~kg} \mathrm{kg"')}$, and incubated in 1-L air-tight canning jars in the presence of $10 \mathrm{~mL}$ of $0.5 \mathrm{M} \mathrm{KOH}$ at $26^{\circ} \mathrm{C}$ for 10 days. The quantity of $\mathrm{CO}_{2}-\mathrm{C}$ absorbed in the alkali was determined by titration (Anderson 1982). Soil microbial biomass $\mathrm{C}$ was determined from the following equation:

$$
\mathrm{SMBC}=\left[\mathrm{mg} \mathrm{CO}_{2}-\mathrm{C} \mathrm{kg}{ }^{-1} \text { soil }(10 d y)^{\overline{1}}\right]_{\text {funigat }} \mathrm{kc}
$$

where $k c=0.41$ (Voroney and Paul 1984).

Mineralizable $\mathrm{C}$ was estimated from the quantity of COi-C and net NKt-N $+\mathrm{NO}_{3}-\mathrm{N}$, respectively, released from an unfumigated sample during 10-day incubation at $26^{\circ} \mathrm{C}$ and a soil water potential of $-30 \mathrm{~J} \mathrm{~kg}-1$ (Campbell et al. 1991). Specific respiratory activity of soil microbial biomass $\mathrm{C}$ was estimated by dividing the net potential microbial activity (i.e., mineralizable $\mathrm{C}$ ) by the size of the SMBC (Campbell et al. 1991).

Particulate organic matter (POM-C) was determined by a modified version of the Cambardella and Elliot (1992) method. POM-C was isolated by dispersing $30 \mathrm{~g}$ of soil in sodium hexametaphosphate and passing the dispersed sample through a 53-(am sieve, which retains the POM fraction + sand and allows the passage of mineral associated soil organic matter. The sand and POM fraction was dried at $50^{\mathrm{D}} \mathrm{C}$, finely ground and subsampled for total organic C.

Water soluble organic C (WSOC) was determined by the method of Mazzarino et al. (1993). Soil suspensions (1:2 soil:distilled water) were shaken for 30 minutes at $150 \mathrm{rev} / \mathrm{min}$ then centrifuged for 5 minutes at $2500 \mathrm{rev} / \mathrm{min}$ and filtered through Whatman no 42 filter paper that had been rinsed with distilled water. Carbon in the extract was determined following Nelson and Sommers (1982).

Current method for inventory of soil organic matter is based on an estimate of the soil C stored under natural vegetation and the relative changes due to aspects of human land use. In this case, calculation of a ratio of the measured soil organic $C\left(C_{\text {org }}\right)$ and a reference $C_{\text {org }}$ value for forest (top) soils of the same texture and $\mathrm{pH}$ was 
needed (Van Noordwijk et at. 1997). The ratio of $\mathrm{C}_{\text {org }} / \mathrm{C}_{\text {ret }}$ could be used as a 'sustainability indicator'. If the value of $\mathrm{C}_{\mathrm{Qrog}} / \mathrm{C}_{\text {ref }}$ ratio is 1 , this means the soil is similar to that of forest, and/or is a "fertile soil"; values towards 0 mean "infertile soil". The current equation for $\mathrm{C}_{\mathrm{re}} \mathrm{f}$ for upland soils in Sumatra (excluding peat and wetlands soils as well as recent volcanic andisols) is :

$$
\mathrm{C}_{\text {ref }}=\left(\mathrm{Z}_{\mathrm{S}} / 12.5\right)^{-0,158} \exp \left(1.333+0.00994 * \text { Clay\%+0.00699*Silt\%-0.156*pH-KCl) where } \mathrm{Z}_{\mathrm{s}}=\right.\text { soil }
$$
sampling depth, $\mathrm{cm}$

\section{Statistical Analysis}

One-way analyses of variance (ANOVAs) procedures were performed to compare the effects of different land-use/ land management on physical, chemical and biological properties of soil. The LSD procedure was used to separate the means of the soil properties at the 0.05 probability level as significant.

\section{RESULTS AND DISCUSSION}

Soils under cultivation had higher bulk densities than other land-use type (Table 1.), with an associated decline in porosity and saturated hydraulic conductivity. The bare and cultivated soils were slightly lower in silt and clay than adjacent soils under natural forest, most likely as a result of preferential removal of silt by accelerated erosion during the rainy season (Handayani 2001). The lowest saturated hydraulic conductivity was found in bare soils and the highest occurred in natural forests. Beginning tillage practices resulted in higher saturated conductivity in cultivated soils compared to bare soils and grassland. Lower plants residue/ organic input probably accounts for the higher bulk density and decreased porosity under cultivation as compared to the natural forest, bare land and grassland soils (Table 1.).

Enhanced soil water content at field capacity and saturated hydraulic conductivity in natural forest is consistent with greater input of labile $\mathrm{C}$ contributed by the high quality litter-fall and root exudates as indicated by higher WSOC and SMBC (Table 3.). During the processes of $C$ turnover, extracellular polysaccharides were produced and with association of root extension have created better soil aggregation (Elliot 1983; Cambardella and Elliot 1992), which caused higher soil water content at field capacity and saturated hydraulic conductivity. On the other hand, organic matter in cultivated soils is less physically protected than that of bare and grassland soils because tillage periodically breaks up macroaggregates and exposes previously protected organic matter in soil macroaggregates (Gupta and Germida 1988), causing more compacted soils (poorer soil aggregation).

Total nitrogen content of soils under cultivation were lower compared to levels in natural forest soils. However, cultivated soils have higher total $\mathrm{N}$ than that in bare land and grassland soils (Table 2.), as might be expected in a system dominated by 
BIOTROPIA No. 22, 2004

Table 1. Selected soil physical properties under different land-use of similar soils in Bengkulu Province, Sumatra.

\begin{tabular}{|c|c|c|c|c|c|c|c|}
\hline Land-use types & Soil texture & $\begin{array}{l}\mathrm{FC} \\
(\%)\end{array}$ & $\mathrm{BD}\left(\mathrm{g} / \mathrm{cm}^{3}\right)$ & $\begin{array}{c}\text { Porosity } \\
(\%)\end{array}$ & $\begin{array}{c}\text { Ksat } \\
(\mathrm{cm} / \mathrm{min})\end{array}$ & $\begin{array}{l}\text { Clay } \\
(\%)\end{array}$ & $\begin{array}{l}\text { Silt } \\
(\%)\end{array}$ \\
\hline Natural forest & Silt loam & 30.48 & 1.02 & 60.50 & 0.853 & 28.16 & 36.71 \\
\hline Bare land & Silt loam & 23.43 & 1.06 & 60.00 & 0.215 & 23.38 & 29.82 \\
\hline Cultivated land & Silt loam & 22.98 & 1.40 & 47.20 & 0.504 & 22.74 & 33.92 \\
\hline Grassland & Silt loam & 15.23 & 1.19 & 55.23 & 0.419 & 22.89 & 31.41 \\
\hline $\operatorname{LSD}(p . \leq 0.05)$ & - & 16.98 & 0.10 & 5.8 & 0.283 & ns & ns \\
\hline
\end{tabular}

* Means of duplicate analysis of three sites for each land-use type. FC = Gravịmetric soil water content at field capacity, $\mathrm{BD}=\mathrm{Bulk}$ density, $\mathrm{Ksat}=$ Saturated hydraulic conductivity.

Table 2. Selected soil chemical properties under different land-use of similar soils in Bengkulu Province, Sumatra.

\begin{tabular}{lccccccc}
\hline \multicolumn{1}{c}{$\begin{array}{c}\text { Land-use } \\
\text { types }\end{array}$} & $\begin{array}{c}\text { Corg } \\
(\mathrm{g} / \mathrm{kg})\end{array}$ & Cref & Corg/Cref & $\begin{array}{c}\text { N total } \\
(\mathrm{g} / \mathrm{kg})\end{array}$ & $\begin{array}{c}\mathrm{pH} \\
(1: 2.5)\end{array}$ & C/N ratio & $\begin{array}{c}\text { N inorganic } \\
(\mathrm{mg} / \mathrm{kg})\end{array}$ \\
\hline Natural forest & 38.90 & 36.3 & 1.07 & 2.74 & 4.0 & 16.42 & 27.38 \\
Bare land & 29.00 & 31.4 & 0.92 & 1.79 & 4.3 & 11.89 & 10.32 \\
Cultivated land & 26.00 & 32.2 & 0.81 & 2.20 & 4.3 & 8.75 & 18.73 \\
Grassland & 29.90 & 32.6 & 0.92 & 2.09 & 4.1 & 18.86 & 22.74 \\
LSD (p<0.05) & 5.19 & - & - & 0.0454 & $\mathrm{~ns}$ & 3.81 & 7.367 \\
\hline
\end{tabular}

* Means of duplicate analysis of three sites for each land-use type.

nitrogen fixing crops such as peanut and bean. The organic $C$ levels were significantly higher in natural forest than those of bare land, 'cultivated land and grassland soils. The $\mathrm{C} / \mathrm{N}$ ratios were wider under undisturbed ecosystems such as natural forest and grassland, indicating higher $\mathrm{C}$ accumulation or slower decomposition resulted in $\mathrm{C}$ stabilization inside soil aggregates (Handayani et al. 1995; Feller and Beare 1997). Bare land and cultivated soils had lower inorganic $\mathrm{N}$ content than that of natural forest and grassland. These proved that less available- $\mathrm{N}$ were released through mineralization under disturbed sites; because these ecosystems had lower $\mathrm{N}$ stock from labile $\mathrm{N}$ pools, such as in soil microbial biomass $\mathrm{N}$ and paniculate organic matter $\mathrm{N}$ (POM-N) (Unpublished results 1999).

The lower levels of total $\mathrm{C}$ and $\mathrm{N}$ in bare land and cultivated soils may have resulted from a combination of lower $C$ inputs because of less biomass $C$ returned and greater $C$ losses because of aggregate disruption, increased by tillage, plant residue burning, and enhanced soil erosion during rainy season (Scott et al. 1994; Handayani 2000). The trends toward lower total C and N in the disturbed land is probably caused by the breakdown of aggregates (Gupta and Germida 1988; Blair et al. 1995), and greater organic matter oxidation following deforestation (Handayani et al. 2001) and continuous tillage (Handayani and Coyne 1999). 
from biomass burning on the bare land and cultivated soils could have returned base-forming cations to increase $\mathrm{pH}$ of surface soil.

The ratios of Corg/Cref were almost similar in bare land, cultivated land and grassland (Table 2 ) with value of $0.92,0.81$ and 0.92 , except for natural forest is 1.07 . The average $C_{\text {org }} / \mathrm{C}_{\text {ret }}$ ratio of 1.07 under forest, suggesting that the soil $\mathrm{C}$ status of this forest has increased. Forest conversion tends to reduce the $\mathrm{C}_{\text {org }} / \mathrm{C}_{\text {rct }}$ for all deforested sites. As suggested by van Noordwijk et al. (1997), if the value of $\mathrm{C}_{\text {org }} / \mathrm{C}_{\mathrm{re}} \mathrm{f}$ ratio is 1 , this means the soil is similar to that of forest, and/or is a "fertile soil"; values towards 0 mean "infertile soil". Therefore, all of deforested areas relatively have infertile soil, with the worst case found in cultivated field. The $\mathrm{C}, \mathrm{g} g / \mathrm{C}_{\mathrm{re}}$ f of cultivated fields was about $24 \%$ less than that of remnant forest. Grassland apparently maintains only slightly higher soil C levels than the bare land. As may be expected that grassland have higher total $\mathrm{N}$ and available $\mathrm{N}$ compared to bare land (Table 2.). The ratio of $\mathrm{C}_{\text {org }} / \mathrm{C}_{\mathrm{re}} \mathrm{f}$ in the forest for this study was higher compared to the study in Sumberjaya, West Lampung Sumatra. Hairiah et al. (2002) reported the value of $\mathrm{C}_{\text {org }} / \mathrm{C}_{\text {ref }}$ under forest condition was 0.73 , suggesting that the soil $\mathrm{C}$ content in the forest has declined from the undisturbed condition. In addition this ration in coffee farming systems was about $50 \%$ less that of remnant forest.

The values of all of the measured biological properties were significantly higher in natural forest than in cultivated soils, except for mineralizable C (Table 3.). Mineralixable C rates did not vary significantly among sites, but tended to be somewhat higher in the soils under natural forest. High rates of mineralizable $\mathrm{C}$ can occur either as a result of large pool of labile $\mathrm{C}$ substrates or rapid oxidation of a smaller pool. Thus high mineralizable $\mathrm{C}$ may indicate a high level of ecosystem productivity and soil bioactivity (Mazzarino et al. 1993).

A more clearly interpretable parameter is the rate of mineralizable $C$ per unit SMBC (specific respiratory activity of soil microbial biomass $C=$ SRAC), high levels of which have been associated with ecosystem stresses (Killham 1985; Handayani and Coyne 1999). The highest SRAC was found in cultivated soils (24.03\%) and the lowest was in natural forest soils $(19.74 \%)$ (Table 4.). Enhanced microbial activities in soils under natural forest are related to greater levels of substrates $\mathrm{C}$, which resulted in the increase of the labile fraction of $\mathrm{C}$ organic. As a result, soil microbial communities under cultivated soils are less biologically active and more stressed than in natural forest. In addition, relatively higher rates of SRAC for the cultivated soils suggest that intense competition for the available $\mathrm{C}$ may favor those microorganisms which use more $\mathrm{C}$ energy for cell integrity and maintenance than for growth under perturbed or disturbed ecosystems. Consequently, cultivated soils favor bacteria-based food webs which have low $\mathrm{C}$ assimilation efficiencies and faster turnover rates than the more efficient fungal-based food webs dominant in untilled or natural ecosystems (Hendrix et al. 1986). A lower SRAC implies a more stable and mature system (Turco et al. 1994), thus this calculation may be a good indicator of status of a soil and therefore, its soil quality (Insam and Hasselwandter 1989).

The highest decline of SMBC was in cultivated soils (42\%) and the lowest occurred in bare land soils (22\%). The effect was more pronounced on POM-C 
(50\% reduction). Undisturbed ecosystems (natural forest and grassland soils) have the lowest WSOC compared to cultivated and bare land soils. Data in Table 3 describe the variety amount of labile $\mathrm{C}$ pools under different land-use types, but the availability of labile $\mathrm{C}$ pools are shown in Table 4. Microbial biomass $\mathrm{C}$ is often limited in size by the availability of C-labile substrates and is sensitive to variations in land-use and soil management practices, so a lower proportion of SMBC in cultivated and grassland soils is an indication of degradation of available pool C in soils under cultivated and grassland soils. Clearing and burning tend to decrease root production in bare land and cultivated soils. Lower root biomass and removal of clipping resulted in lower substrates availability, and thus lower SMBC.

Table 4. Effect of land-use on the properties related fractions of soil organic matter at adjacent areas of similar soils in Bengkulu Province, Sumatra.

\begin{tabular}{lcccc}
\hline \hline \multicolumn{1}{c}{ Land-use types } & $\begin{array}{c}\text { Min-C/SMBC } \\
(\%)\end{array}$ & $\begin{array}{c}\text { SMBC/C org } \\
(\%)\end{array}$ & $\begin{array}{c}\text { WSOC/C org } \\
(\%)\end{array}$ & $\begin{array}{c}\text { POM-C/C org } \\
(\%)\end{array}$ \\
\hline Natural forest & 19.74 & 1.165 & 3.497 & 22.32 \\
Bare land & 22.18 & 1.221 & 6.586 & 16.58 \\
Cultivated land & 24.03 & 1.210 & 6.120 & 16.73 \\
Grassland & 22.30 & 1.00 & 4.510 & 13.34 \\
\hline
\end{tabular}

Min- $\mathrm{C}=$ Mineralizable $\mathrm{C}, \mathrm{SMBC}=$ Soil microbial biomass $\mathrm{C}, \mathrm{WSOC}=$ Water soluble organic $\mathrm{C}$,

$\mathrm{POM}-\mathrm{C}=$ Particulate organic matter.

WSOC appears to be the intermediate organic substrate for soil microorganisms (McGill et al. 1986). Turnover of SMBC requires repleshnisment of WSOC supplies. Repleshnisment mechanisms include desorption from soil colloids, dissolution from litter, exudation sloughing and exfoliation from plant roots, or hydrolisis of insoluble soil organic polymers (McGill et al. 1986). Changes in soil environment, soil management and cropping practices would be expected to affect the above mechanisms, thereby altering WSOC supply and both amount and activity of SMBC.The lower proportion of WSOC in C org under undisturbed ecosystems indicates more soil organic matter was in protected condition, so they are not readily soluble or not readily available to microorganisms.

POM-C has been closely associated with the active soil organic matter pool and has been successfully used as an assay of nutrient availability (Dalai and Mayer 1987). Loss of POM-C is an important aspect of soil organic matter degradation. POM-C declined in newly bare soils and cultivated fields and lowest under grassland soils. Our study suggests that POM-C characteristics may also serve as early indicators of soil organic matter aggradation. POM-C accumulated as soil organic matter was restored in natural forest and it is important for $\mathrm{C}$ and nutrient reservoir in soils (Cambardella and Elliot 1992). Values of ratio POM-C/C org indi- 
cate similar trend with values of POM-C which show the highest under natural forest soils and lowest in grassland soils. This implies that availability of POM-C continuously declined when the forest is converted to other land-use type (Table 4.). This study gives an implication that bare land, cultivated and grassland soils have less physically protected soil organic matter compared with natural forest soils, resulting in soil deterioration over time.

The calculation of degradation level determined by scaling technique (Scott et al. 1994), reflects the percent changes in soil properties from their standard values under natural forest (Table 1.). Scaling of soil properties was used to relate the characteristics of one land-use to the same characteristics of another land-use by dividing the mean values of each soil property from the natural forest. Therefore, the values from the natural forest would have a scale of 1.0 and other land-use would have a scale value less than 1.0, indicating the decline of soil quality. All scale values were averaged at each land-use, then subtracted by 1.0 and converted to percentage as indicated by degradation level. In this study, soil properties scale was made on saturated hydraulic conductivity, gravimetric soil water content at field capacity, porosity, $\mathrm{C}$ organic, $\mathrm{N}$ total, inorganic $\mathrm{N}$, mineralizable $\mathrm{C}$, soil microbial biomass $\mathrm{C}$, and particulate organic matter (Table 5).

The calculated soil degradation index reflects the percent changes in soil properties from their values under forest (Table 5). Soils under bare land had the highest degradation index up to $38 \%$ compared to grassland and cultivated soils (33\%) with an average of $35 \%$. The data also indicated that fallowing the land by natural growth grassland of Imperata cylindrica for about 15 years have not improved the soil quality compared to cultivated soils. In some cases, grassland ecosystem often created more deterioration in several soil properties (Table 5.).

These soil degradation indices clearly show that degradation of soil quality occurs when the forest systems are converted for agriculture without the use of appropriate soil conservation practices. 
Soil quality changes following forest clearance - I.P. Handayani

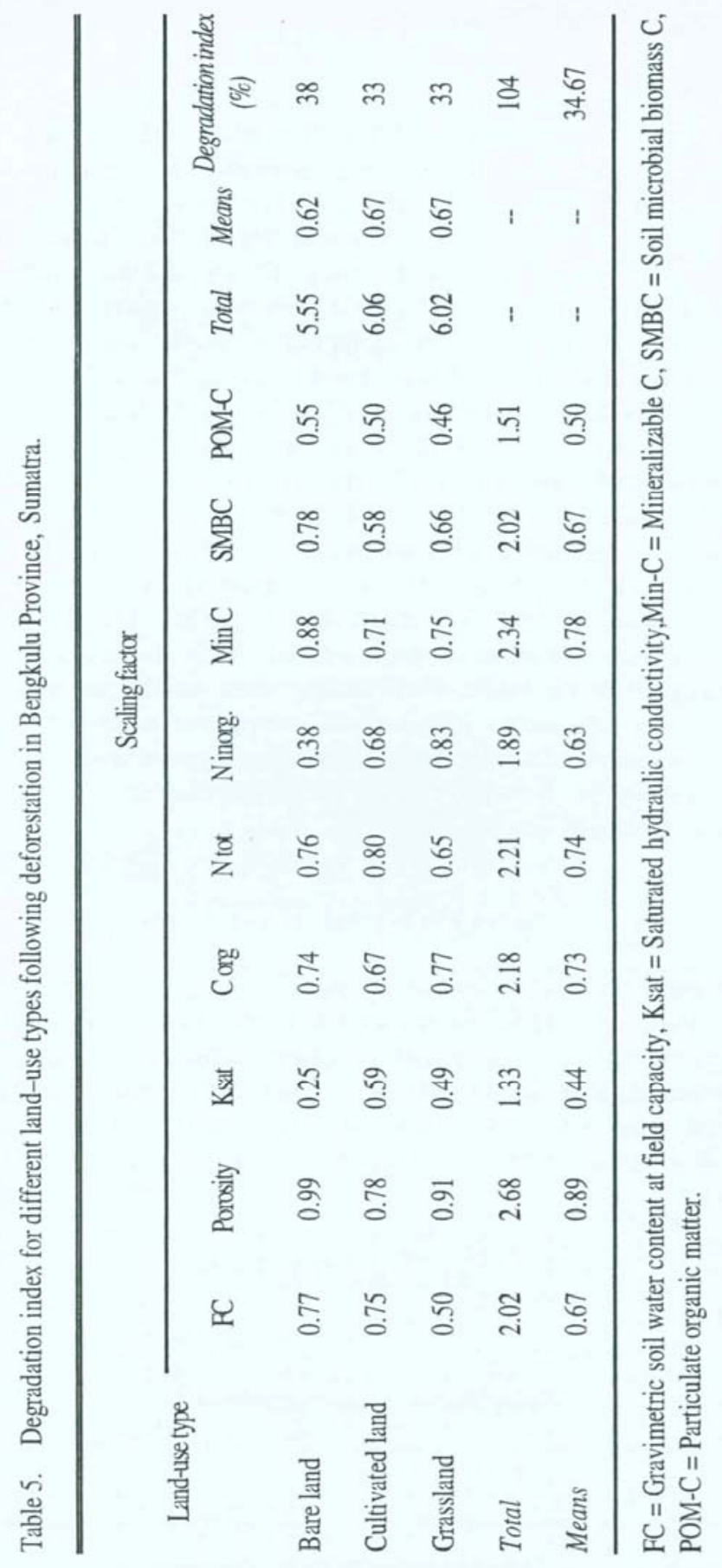




\section{CONCLUSIONS}

Clearing, burning and cultivation of tropical secondary forest lands resulted in degradation of soil quality as indicated by the changes in physical, chemical and biological properties. Land-use following forest clearance decreased saturated hydraulic conductivity by $85 \%$, porosity by $10.50 \%$, soil water content at field capacity by $34 \%$, C organic by $27 \%, \mathrm{~N}$ total by $26 \%$, inorganic $\mathrm{N}$ by $37 \%$, soil microbial biomass $\mathrm{C}$ by $32 \%$, mineralizable $\mathrm{C}$ by $22 \%$, and particulate organic matter by $50 \%$, but slightly increased water soluble organic C. Specific respiration activity rates increased about $14 \%$ in cultivated soils compared to natural forest soils. Forest conversion tends to reduce the $\mathrm{C}_{\mathrm{org}} / \mathrm{C}_{\mathrm{re}}$ f for all deforested sites. All of deforested areas relatively have infertile soil, with the worst case found in cultivated field. The $\mathrm{C}_{\text {org }} / \mathrm{C}_{\text {lef }}$ of cultivated fields was about $24 \%$ less than that of remnant forest. Grassland apparently maintains only slightly higher soil $\mathrm{C}$ levels than the bare land. Bare land and cultivated soils had higher bulk density, lower saturated hydraulic conductivity, porosity and soil water content at field capacity. Based on calculation for the ratio of $\mathrm{C}_{\text {org }} / \mathrm{C}_{\mathrm{re}} \mathrm{f}$, all of deforested areas relatively have infertile soil, with the worst case found in cultivated field. Degradation index of soil following secondary forest clearance was about 35\% in average, with the greatest deterioration occurring in bare land. Fallowing the abandoned land by natural grass has not improved the soil quality. Therefore, improvement of soil properties under Imperata grassland with well-adapted and fast growing vegetative species to compete with these grass is needed to gradually improve soil quality as well as regenerate degraded grassland.

\section{ACKNOWLEDGEMENTS}

This work is a part of the research supported by the Government of Indonesia through the project under the Department of Research and Technology (MENRIS-TEK) and the Department of National Higher Education (DIKTI). The technical assistance of Meizar and Yulian Hardi is gratefully acknowledged. We also thank the local government and local farmers for providing their fields for this study. Special thanks are due to Dr. Meine van Noordwijk for his help in reviewing the manuscript.

\section{REFERENCES}

Anderson, J.P.E. 1982. Soil Respiration, p. 837-871. In A.L.Page et al. (ed.)Methods of Soil Analysis. Part 2. 2"1 ed. Agron. Monogr. 9. ASA and ASSA, Madison, WI.

Arya, L.M. 1990. Properties and processes in upland acid soils in Sumatra and their management for crop production. Sukarami Research Institute for Food Crops. Padang. Indonesia. 109 p.

Blair, G.J., R.D.B. Lefroy, and L.Lisle. 1995. Soil carbon fractions based on their degree of oxidation and the development of carbon management index for agricultural systems. Aust. J. Agric. Res. 46:1459-1466. 


\section{Soil quality changes following forest clearance - I.P. Handayani}

Cambardella, C.A., and E.T.Elliot. 1992. Particulate soil organic-matter changes across a grassland cultivation sequence. SoilSci. Soc. Am.J. 56:777-783.

Campbell, C.A., V.O.Biederbeck, R.P.Zentner, and G.P.Lafond. 1991. Effect of crop rotations and cultural practices on soil organic matter, microbial biomass and respiration in a thin Black Chernozem. Can. J. Soil. Sci. 71:363-376.

Feller, C., and M.H. Beare. 1997. Physical control of soil organic matter dynamics in the tropics. Geoderma79:69-116.

Dalai, R.C., and RJ.Mayer. 1987. Long-term trends in fertility of soils under continuous cultivation and cereal cropping in Southern Queensland. VI. Loss of total nitrogen from different particle-size and density fractions. Aust. J. Soil. Res. 25:83-93.

Elliot, E.T. 1983. Aggregate structure and carbon, nitrogen and phosporus in native and cultivated soils. Soil Sci. Soc. Am. J.50:627-633.

Gupta, V.V.S.R., and J.J.Germida. 1988. Distribution of microbial biomass and its activities in different soil aggregate size classes as influenced by cultivation. Soil Biol. Biochem. 20:777-789.

Hairiah, K., J.Arifin, Berlian, C.Prayogo and M.van Noordwijk. 2002. Carbon stock assessment for a Forest-to-coffee conversion landscape in Malarig (East Java) and Sumber-Jaya (Lampung) Indonesia. Proceedings International Symposium Forest Carbon Sequestration and Monitoring. Taipei, Taiwan , November 11-15, 2002.

Handayani, IP. 2001. Soil quality in grassland and agriculture ecosystem. Jurnal Tanah Tropika 12:135-141.

Handayani, I.P., P.Prawito, P.Lestari and M.S.Coyne. 2001. Potential of carbon sequetration after reforestation and grass establishment on tropical degraded soils.p. 429-440. In B.A. Thielges et al. (ed.) In situ and Ex situ Conservation of Commercial Tropical Trees. GMU and ITTO. Yogyakarta. Indonesia.

Handayani, I.P., and M.S.Coyne. 1999. Dynamics of biologically active C pools in relation to soil organic matter content. Proceedings International Seminar Towards Sustainable Agriculture in Humid Tropics Facing $21^{\text {sl }}$ Century. Bandar Lampung, Indonesia.

Handayani, I.P. 2000. Changes in soil organic matter pool during shifting cultivation in Bengkulu, Sumatra. Jurnal Penelitian UNIB VI(17):22-27.

Handayani, I.P., M.S.Coyne, and R.L. Blevins. 1995. Soil biologically active carbon under long-term no till and conventional tillage. Agron. Abst. ASA and SSSA Annual Meeting, St. Louis, USA.

Hendrix, P.E., R.W.Parmele, D.A.Jr. Crossley, D.C.Coleman, E.P.Odum. and P.M.Groffman. 1986. Detritus food webs in conventional and no-tillage agroecosystems. BioSci. 36:374-433.

Insam, H., and K.Hasselwandter. 1989. Metabolic quotient of the soil microfloral in relation to plant succession. Oecologia 79:174-178.

Jenkinson, D.S., and D.S. Powlson. 1976. The effects of biocidal treatments on metabolism in soil. V. A method for measuring soil biomass. Soil Biol. Biochem. 8:209-213.

Kandeler, E. 1995. Methods in soil chemistry, p. 397-398. In. E.Schinner et al. (ed.). Methods in Soil Biology. Springer. Germany.

Killham, K. 1985. Assessment of stress to soil microbial biomass. p. 79-83. In A.P. Rowland (ed.) In Chemical Analysis in Environmental Research. ITE 18. Institute of Terrestrial Ecology.

Klute, A., and C.Dierksen. 1986. Hydraulic conductivity and diffusivity :Laboratory methods, p. 687-732. In Klute (ed.) Methods of Soil Analysis. ASA and ASSA, Madison, WI. 
Mazzarino, M.J., L.Szott, and M. Jimenez. 1993. Dynamics of soil total carbon and nitrogen. Microbial biomass, and watersoluble carbon in tropical agroecosystems. Soil Biol. Biochem. 25:205-214.

Me.Donald, M.A., J.R.Healey, and P.A.Stevens. 2002. The effects of secondary forest clearance and subsequent land-use on erosion losses and soil properties in the Blue Mountains of Jamaica. Agric. Ecosyst. and Environ. 92:1-19.

McGill, W.B., K.R.Cannon, J.A.Robertson, and F.D.Cook. 1986. Dynamics of soil microbial biomass and water-soluble organic C in Brenton L after 50 years of cropping to two rotations. Can. J. Soil Sci.:66:l-19.

Nakano, K., and K.Syahbuddin. 1989. Nutrient dynamics in forest fallows in Southeast Asia. In Proctor, J. (Ed.). Mineral Nutrients in Tropical Forest and Savanna Ecosystems. Blackwell, Oxford, p. 325-336.

Nelson, D.W., and L.E.Sommers. 1982. Total carbon, organic carbon, and organic matter, p. 539-594. In A.L.Page et al. (ed.) Methods of Soil Analysis. Part 2. $2^{\text {nd }}$ ed. Agron. Monogr.9.ASA and ASSA, Madison, WI.

Riswan, S., and L.Hartanti. 1995. Human impacts on trical forest dynamics. Vegetatio 121: 41-52.

Scott, H.D., I.P.Handayani, A.Mouromostakos, and D.M.Miller. 1994. Temporal variability of selected properties of loessial soil as affected by cropping. Soil Sci.Soc.Am.J. 58:1531-1538.

Shiddieq, D. 1993. Effect of tropical rainforest conversion to agricultural farms on ultisols in Subanjeriji. PhD. Thesis, University of Los Banos, Philippines.

Turco, R.F., A.C.Kennedy, and M.D.Jawson. 1994. Microbial indicators of soil quality, p. 73-90. In J.W.'Doran et al. (ed.) Defining Soil Quality for a Sustainable Environment. SSSA Special Publication no. 35., Madison, WI.

van Noordwijk, M., C.Cerri, P.L.Boomer, K.Nugroho and M.Bernoux. 1997. Soil carbon dynamics in the humid tropical forest zone. Geoderma 79:187-225.

Voroney, R.P., and E.A.Paul. 1984. Determination of kc and kn in situ for calibration of the chloroform fumigationincubation method. Soil Biol. Biochem. 16:9-14. 